\title{
Social Representations of the Guarda Nacional Republicana Militaries. Comparative Study: Territorial Commands of Évora, and Setúbal
}

\author{
FREDERICO FRANCO CHARRO ${ }^{1, \text { a }}$, DAVID PASCOAL ROSADO ${ }^{1,2, ~ b}$, HELGA SANTA \\ COMBA LOPES ${ }^{1, \mathrm{c}}$ \\ ${ }^{1}$ Academia Militar, Lisbon, PORTUGAL \\ ${ }^{2}$ Universidade Europeia, Lisbon, PORTUGAL \\ acharro.fjf@gnr.pt; b david.rosado@,academiamilitar.pt; ${ }^{\mathrm{c}}$ helga.lopes@academiamilitar.pt
}

\begin{abstract}
This paper gains a better $\mathrm{u}$ nderstanding of the relation betw een Guarda Nacional Republicana (GNR) officers and citizens fro $\mathrm{m}$ Évora and Setúbal districts. Currently, boost the rel ationship between militaries and the population it's a strategic goal of Guarda Nacional Republicana, namely work to convey a credible and professional image, contra sting with the soci al representations and old stereotypes that persist in haunting the institution's image from the times of the Estado Novo. In fact, thr ough literature review, surveys and interviews we were able to understand how the social repr esentations of Guarda Nacional Republicana militaries have evolved $\mathrm{s}$ ince the begi nning of the $21 \mathrm{st}$ century in the districts mentioned above, that is, investigate the opinion and representa tion of the society about the $m$ ilitaries by carrying out a comparative study. As main conclusions, we point out that the social representation of Guarda Nacional Republi cana officers have evolved quite positively since the beginning of the 21 st century to the present day, leading us to conclude also that the old stereoty pe (strongly negative for the im age of the military) is almost completely depleted. The study's conclusions also point towards the importance of culture and values, age, ethnicity, and place of residence of the citizens have in relationship and opinion with this professional class.
\end{abstract}

Key-Words: - Guarda Nacional Republicana, Opinion, Representation, Society, Social Representations.

Received: October 17, 2019. Revised: March 9, 2020. Accepted: March 18, 2020. Published: March 26, 2020.

\section{Introduction}

Guarda Nacional Republicana (GNR) is an organ of Portuguese State, has as its fundamental tasks, in addition to those provided for in its Organic Law, ensure compliance with all the paragraphs of article 9 of Portuguese Republic Constitution [ 1], from which we highlight the promotion and quality life of Portuguese citizens and the real equality among the Portuguese.

Beyond State organ [ 2], Guarda Nacional Republicana is one of the other Security Forces in Portugal, along with Polícia de Segurança Pública (PSP), which constitute the Portuguese dualist police system. Accordingly, as provided for in article 272 of the Portuguese Republic Constitution, GNR's role is "defend democratic legality and guarantee internal security and citizens' rights" [34 ] and as a police institution " $m$ ust ensure public support to provide efficient and effective services" [34].

In fulfillment of their $\mathrm{m}$ ission, GNR militaries are governed by the institution's motto "By law and by people" and various principles of action, as provided in article 7 of the GNR Service Regulation [3]. It states " $m$ ilitaries must maintain a proper relationship with citizens, using correctness, courtesy, and good conduct, proceeding in such a way as to preserve the confidentiality, consider and render prestige inherent to the functio ns providing all assistance (...) who asked them" [3].

At this st age of framin $\mathrm{g}$, article 11 of GNR Military Statute, located in section II thereof, provides in paragraph one that militaries must adopt "ethical conduct and act integrated and professionally competent, to strengthe $\mathrm{n}$ population trust and respect" [4].

Therefore, determining social representations about GNR officer's/m ilitaries understands way $\mathrm{s}$ people use to conceive transform and interpret behaviors and attitudes linked with thos e officers. It allows us to identify, create and generate opini ons, thoughts, feelings, perceptions, and experiences shared in a specific geographic area or type of population. This is because there are $\mathrm{n}$ ot individual or rootless social represe ntations of e ach person's connections, so ways of thinking, feeling and acting can never be individualized.

The protection of the pop ulation and g uarantee the credibility of the officers' actions are, therefore, fundamental activities for Guarda Nacional Republicana, so it' $s$ extremely important to understand the opinion and image th at population has about th em, with purpose to ide ntify social 
behaviors and social $\mathrm{f}$ actors that aff ect stereotypes and social representations about the officers.

As we know, there have $b$ een periods in the past when GNR's image and opinion were quite negative. Tyler and Wakslak [37] warn us that people place a high value on dignified and respectful treatment by legal authorities. However, in the past, more specifically during Estado Novo, GNR is characterized by a repressive, aggressive and disrespectful attitude towards citi zens, which contributed to a bad image and negative stereotype.

Nowadays, GNR's mission is benefiting th $\mathrm{e}$ relationship with society and with the citizen knowing that levels of proxim ity and trust slowly and gradually evolving, as expressed by Reiner [29], trust does not suddenl y change, progr esses slowly over time.

Furthermore, according to Thom assen, Strype and Egge study "negative experiences $h$ ave a more powerful effect on trust than do positive experiences" [36], situations that make it difficult to fulfill the GNR mission.

After a brief legal fram ework of fundam ental tasks performed by GNR to benefit society and citizens, it is relevant to understand if social representations and images/opinions of the population have been changed in the 1 ast years or not. Having for on the ground that they are rather derogatory between the seventies and eighties of the previous century. Also, whether or not the geographical and therefore cultural factor is a decisive criterion for GNR militaries image, opinion, and perception.

\section{Fieldwork and Research Methodology}

\subsection{Type of Research}

This is a stu dy that followed the soci o-critical paradigm, fulfilled with reasoning and hypotheticaldeductive method with a mixed strategy of in quiry, including a qualitative approach and a quantitative approach.

We began from a constructionist position, in the assumptions "that ther e may be many different realities", and that we needed "to gat her multiple perspectives through a mixture of qualitative and quantitative methods and to collect the views and experiences of diverse individuals and observers. (...) sometimes described as triangulation" [8].

\subsection{Sampling}

Fortin defines the sa mple as the "s et of all persons or other elements of a well-defined group , with one or several si milar characteristics in common, which is the base for a research" [10]. The sample gathers a range o $f$ information about the population available, this is exactly what Quivy and Campenhoudt point ou $t$ when they refer to it as "understood in its broadest sense: the set of elements of a whole" [28].

Our sample was select within the population of Évora and Setúbal districts, in the areas of G NR jurisdiction, focusing on main cities of these. For the interview, the script covered 9 individuals, who were Territorial Commanders officers, GNR senior officers, Journalists with security experts and members of city councils. Therefore, they are part of the interview panel two lieutenant colonel, one from each district, three captai ns, one lieutenant and a 2nd lieutenant from GNR.

In addition to these, are also the executive councilor of Almada, Francisca Parreira, she is responsible for civil pr otection and security in the council. Lastly, José Vegar, who has a master's degree in so ciology and collaborates with major newspapers in Portugal.

Similarly, our sa mple for the survey $\mathrm{s}$ is representative of the population, consisting of 105 citizens, 40 of them were conducted in Évor a district and 65 in Setúbal district, to coincide with the actual population living in these districts and main counties, as shown in Figure 1.

Figure 1: Frequency of Surveys for Co unty (Authors' elaboration).

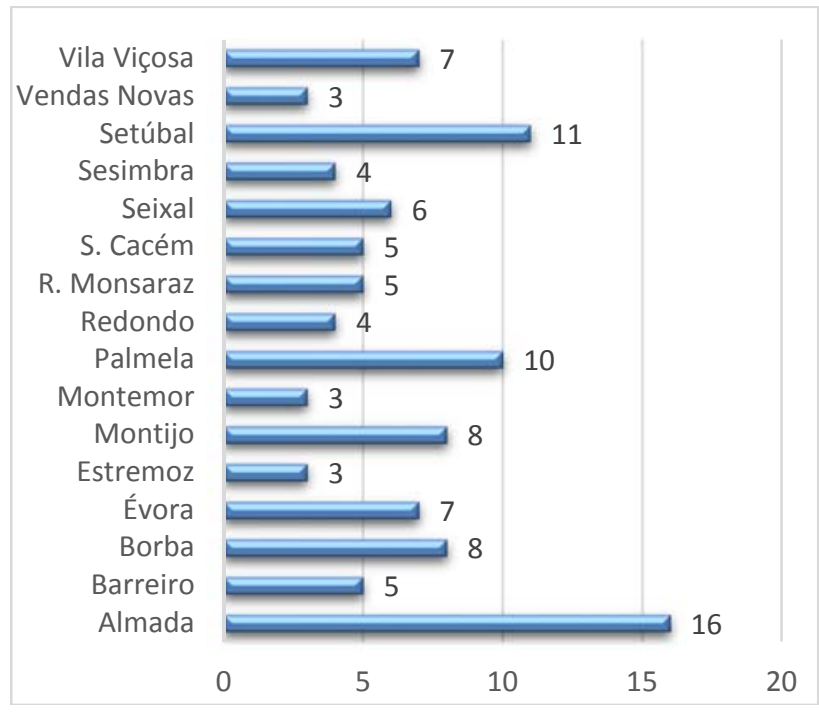

To get a global view on the matter in study these 9 people interviewed and 105 respondents, who have different opi nions, experiences and visions 
than GNR o fficers represent different generations (from 20 to 70 years old), as shown in Figure 2.

Figure 2: Frequency of Respondents Age ( Authors' elaboration).

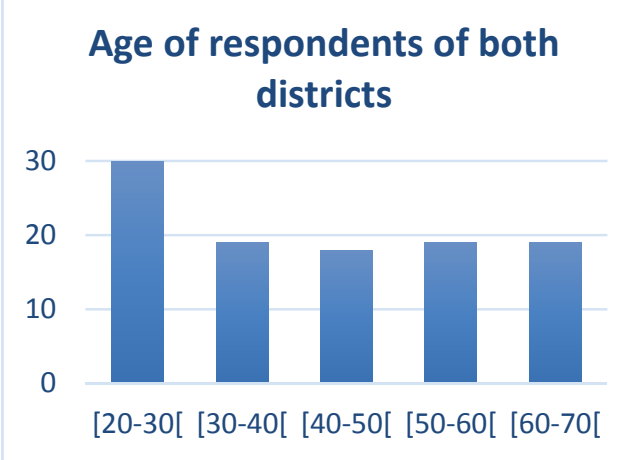

Of these 105 respondents, regarding their gender, we can say that there was an equivalent distribution in both districts for this $\mathrm{v}$ ariable. In total, 53 men and 52 women answered the questionnaire, divided according to Figure 3.

Figure 3: Gender Frequency of Sur veys (Authors' elaboration).

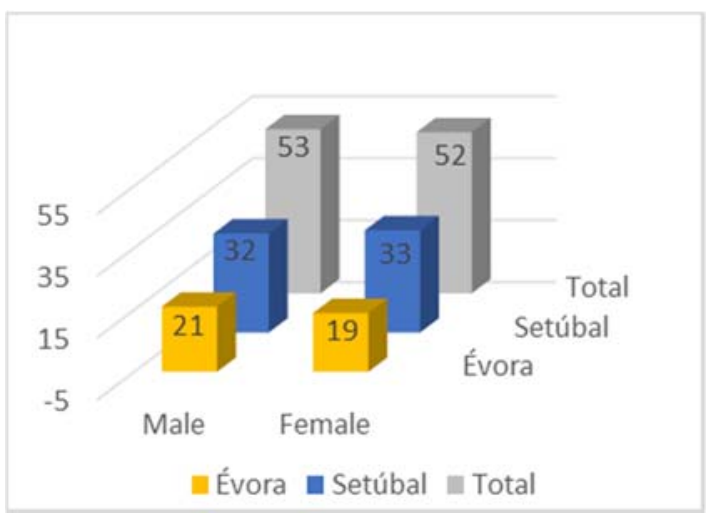

\subsection{Instruments}

In the research development, the data collection instrument was not only the survey $\mathrm{s}$ by the questionnaire but also the interviews. As Marconi and Lakatos an intervie $\mathrm{w}$ is "an instru ment par excellence of social res earch"[17]. It presents advantages that the "resear cher's interlocutor expresses his perceptions of an event or situation and his interpretations" [28].

Therefore, the interview al lows for exploring the behavior, perspectives, and experiences of the interviewed individuals [42]. In this way, it allows us, researchers, to "dr aw very rich reflection elements" [33] for research.

Firstly, we carried out bibliographic resear ch on several authors to organ ize the methodological part.
Then, we extended our bibliographic research to books, magazines, articles and consu lted several online platforms to collect all pertinent information related to the theme of Social $\mathrm{R}$ epresentations and history of the image and opinion of the population regarding GNR officers.

We have formalized the data collection through surveys by questionnaire. As Fortin referred it "serves to collect information along with the population related to the prevalence and distribution of psychosocial problems and how these populations maintain relationships between them"[ 10] from which the necessary conclusions were withdrawn to answer the central question.

Surveys were performed between March and April 2019. Surve y answers were mostly made through paper format, but to achieve a higher sample size, they are also distributed online trough Google platform. There was a constant concern during data collection to ensure citizens' anonymity to increase the reliability of results.

\subsection{Procedures}

From Quivy and Campenhoudt point of view, a procedure is designed to "progress towards a goal" [28]. To accomplish our research, we started with a theme and then we defined the central question.

After outlining the central question, the study was delimited, and then the associated three subquestions were established.

This study relied on the responses obtained through surveys by close questionnaire, since "the questionnaire is one of the data collection m ethods that require written responses to a set of questions on the part of the subjects" [10].

Likewise, interviews were conducted with some Specialists in security to obtain the greatest amount of information pertinent to elaborate on the intended analysis.

Lastly, the results were aggregated in a database through informatics support.

\section{Related Background and Theory}

The related backgroun ds aim to gain a better understanding of the paper's core concepts as well as the fr aming of social representat ions within sociology and all the factors inherent in them.

\subsection{Core Concepts}

\subsubsection{Historical Framework}

Sociology foundations draw us back to remarkable historical epochs of Hum anity, such as Renaissance (14th t o 16th c entury) and 
Enlightenment (18th century) and lat er are fully related to li beral ideas of American and French Revolutions. Within this discipline, it is essential to highlight authors such as Auguste Comte (17981857), Émile Durkheim (1858-1917), as well Karl Marx (1818-1883) and Max Weber (186 4-1920) because they were the great founders and drivers of Sociology. Comte was the first author to use the Sociology term, but the French often used "social physics" to nickname the discipline. In his opinion, Sociology must apply to the study of society the scientific methods, which were used by chemistry or physics. Durkheim, in turn, finally gives a scientific character to Sociology. These two authors were the great drivers of one Sociology theoretical currents, functionalism [30].

Karl Marx radically contradicts the ideas and thoughts of French sociologists and i s the driving force behind the perspective of conflict, another theoretical current. His perspective is based on economic values, that is, so cial changes are driven above all b y economic factors and social stratification and not b y human values or beliefs. Later, Weber proved quite critical of Marx' s thinking and his approaches to social change. Max Weber placed econom ic values, ideas, beliefs and values on the same level of importance, all having the same impact on social change. Thus, the German sociologist, along with George Mead (1863- 1931), was a supporter of the theoretical current, s ymbolic interactionism, as shown in the following sche me [30].

Figure 4: Theoretical Currents of Sociology (Authors' elaboration).

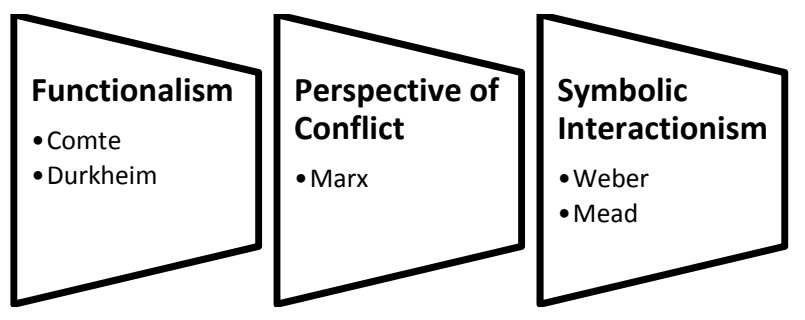

After World War II, the disciple is com pletely devastated on European so il, so it $\mathrm{w}$ as forced to cross borders continue to assert itself as a science. At this st age emerged the Americans living in a prosperous economic and social perio d, in contrast to European countries devastated by war. Therefore, Americans were instrumental in bringing sociology to "a stage of $m$ aturity that (...) enable to reach the international destiny of discipline" [13].

\subsubsection{Sociology}

Sociology can send us to am biguity and complexity since it is a discipline linked to tem poral and spatial contingencies that aim to analyze human beings through relationships that establish a societ $y$ and a culture. However, e merges as "an attempt to understand the radical changes that have occurred in human societies" [11] and the $m$ ain objective of sociological work is contributing to improving the knowledge of societies always keeping in mind the enormous complexity of the object of stud $y$, dependent on social causalities and instability associated with social situations.

Sociology can still be dubbed as " moral science" because it has an irreplace able character in terms of "imposition of values and the very principles of life in society" [13].

Thus, Sociology can be defined as "sci ence that studies the behavior of human beings in society through facts, considering different categorizations, interactions, groups, organizations, and institutions, in structures and processes that make up a social organization to understa nd and consequentl $\mathrm{y}$ improve social context" [30 ]. Giddens, in turn, defines it as "the study of human social life, groups, and societies. It is a fascinating and em barrassing task, as the subject of study is our behavior as social beings" [11].

\subsubsection{Culture}

Culture is a term that comes from "Latin culture" [24] and according to Yeats " $i$ s the holiness of the intellect" [22].

When looking up "culture" in Contem porary English Dictionaries, it is possible to infer tha $t$ culture refers to "the beli efs, way of life, art and customs that are shared an d accepted by people in a particular society" [25]. May also be associated with the "attitudes and beliefs about som ething that are shared by a particular group of peo ple or in a particular organization" [25].

Nowadays the culture is more commonly defined as a set of "meanings and interpretations that are a consequence of the history of this specific social context, where various s ocial representations of reality have been co mpassionately constructed" [30].

\subsubsection{Social Representations}

Social is a term that comes from "Latin Socialis" [23]. Representation, in its turn, com es from "Latin Representationem" [24] and means a "statement made regarding a subject" [24].

After that, in the 1960s, Moscovici was the major driver of social $r$ epresentations, concerning 
Durkheim's collective representations. The social representation concept is quite divers e and multifaceted. Moscovici (1976) warns us that "if it is easy to grasp social representation reality it is not to eas $y$ to grasp the concept" [20].

Social representations represent a combination of values, ideas or practices that ar e socially constructed. They allow sharing the realit y, influencing people's lives, in their relationship with the world and guide their conduct ([14]; [19]) or as "a form of knowledge, socially elaborated and shared, having a practical facet and contributing to a construction of a common reality to a social group" [20].

In Doise perspective, soc ial representations are generating principles of positions linke $d$ to specific insertions in a set of social relations and organize symbolic processes involved in these relations, which emphasizes the relationship between social representations and certain social structural factors such as social or status position [7].

According to Neto, in general, anchoring reflects the intervention of represe ntation in the social and objectification consists of the intervention of social factors in representation [21].

In Moscovici opinion, anchoring consists of incorporate information in groups or classes, in preconceived schemes, thus facilitating the designation of objects and events, their classifi cation, as it gives them a certain meaning [19]. This contributes to the interpretation of facts, construction of opinions an $d$ behaviors.

On the other hand, as Neto characteriz es, objectification enables the realization of so mething abstract, as it attributes particularities, groups' images and makes $r$ eal and visible what is not palpable. It occurs a construction of a new reality and it is not feasible to differentiate what is mentally produced from objective reality [21].

From Jodelet point of view, it is im plicit that a person does not respon $\mathrm{d}$ so $\mathrm{m}$ uch daily to a concrete, objective, quantifiable reality, but rather to a reality constructed, altered and following preconceived schemas resulting from an entire existential history and which socializ ation of each person plays a fundamental role in their construction [14]. These constructions are constantly changing throughout the life of each person, being determined by inherent factors, ideology followed and social environment that surrounds it, assu ming importance and relevance the relationship $\mathrm{t}$ hat a person maintains with the same.

Finally, Sampaio, Oliveira, Vinagre, Pereira, Santos, and Ordaz advise that subjective conceptions must be carefully analyzed, since social representations will serve as patterns of reading and interpretation of reality and, consequently, determine behaviors and attitudes [32].

In brief, social repre sentations are reading patterns and interpretations of reality that determine behaviors, attitudes and build images and opinions.

\subsection{Guarda Nacional Republicana}

\subsubsection{Mission and Assignments}

As a body of Portuguese State and responsible for guaranteeing democratic freedom, as provided in article 1 of GNR organ ic law, GNR guarantees internal security and also collaborates, $i \mathrm{f}$ necessary, in matters related to national defense policy [2].

GNR's attributions are for eseen in artic le 3 of GNR organic law, highli ghting for the research theme, paragraph a), b) and i) [ 2]. In addition to the above-mentioned articles, the GNR Service Regulation, in number 2 of article 109, that GNR must "ensure a stable link between the institution and its surroundings to inc rease the credibility and reputation of its image"[3].

According to Lieutenant General Silva Couto, GNR General Commander, vision under the GNR Strategy 2020, GNR "must be a close and reliable human security force that is distinguished by excellent service provides and is recognized as the benchmark in the field of security" [12]. Then, building citizens' confidence in the insti tution will also be a co ncern and a strategic obje ctive to be achieved.

Since the im plementation of new forms of policing, in particular, proximity policing with special programs, the relationship bet ween GNR militaries and citizens have greatly enriched and strengthened as it has fostered creating a credible, professional image and opinion of the militaries.

Proximity policing, of Belgian and French origin, is defined as "a for $\mathrm{m}$ of security management, implemented close to the population, to respond, through preventive police action, to their carefully identifie $d$ needs and taken into consideration" [23]. Together with special programs, they are instrumental in creating an empathic and solid relationship between GNR as an institution and society. $T$ yler considers that these mechanisms are central to ensure police credibility [39], and "there is strong evidence that police personal contact and visibility are of central importance to police trust and legitimacy" [5].

"One of the main purposes of GNR Command is to consolidate the instit ution (...) by enhancing human vector and $\mathrm{k}$ nowledge management, 
combining efforts to promote proximity to populations" [12], strengthen people's confidence in GNR by creating a mutual relationship of trust. However, it is a long $\mathrm{j}$ ourney, as "most important in one-to-one interactions between police and public members are c ourtesy, respect, and responsibility" [9] conduct that should be cultivated in GNR militaries to promote proximity to citizens.

In this sense, GNR ado pted, in conjunction with proximity policing, the Anglo-Saxon concept of community policing, where partnerships and relations are formed between citizens and militaries, based on the idea that GNR and communities should work and join efforts to find solutions to society's problems.

Community policing is defined as "a philosophy and organizational strategy that seeks a new partnership between people and the police. It is based on the idea that police and community have to work together" [ 23]. With this, the community becomes invol ved in security dynamics, whose phil osophy constitutes a true principle of citizenship significantly improving social representations and, of course, the military's image.

\subsubsection{Image, Opinion, Perception and Satisfaction}

In our da ys "legal authorities (...) are in a structural position that $\mathrm{m}$ akes it difficult to ensure satisfaction, encourage deference and build trust and credibility among public members" [38].

GNR has a great national and international notoriety as a result of th e image that has been worked out exhaustively, in recent y ears, having as its main objective satisfy citizens need $\mathrm{s}$ and ensure that they have a credible image of Guard and his officers.

According to Lindon, Lendrevie, Lévy, and Dionísio, image is a concept close to the recipient; it is subjective, simplifying and stable conception of a product, institution or in dividual, as well as the associations and perceptions associat ed with the $\mathrm{m}$ [16].

Therefore, an image translates into a set of associations that we ret ain in memory (Aaker and Keller cited in [27]), thus becom ing extremely complicated, changing a negative and derogatory image applied in a social context for several years and, that goes from generation to generation without changing.

Each person has a different perception of reality than the othe rs so, there are disparate images and opinions about GNR officers in Portuguese society.
This paradigm is reinforced by Dowling in standing that "an organization does not have o nly one image but several, depending on the subjective concept (beliefs, values, feelings) in which different mental associations" [31].

Satisfaction concept is closely linked to the image and as Marcos and Loureiro involve a comparison between the expectations of citizens and the perception of the officer's service[18]. According to Skogan, society's sources of satisfaction with police are mainly "linked to age, ethnicity/race, and language ability " [35]. Schafer, Huebner, and B ynum agree with Skogan because they state, "ethnicity is one of the main demographic characteristics found to $b$ e associated with police perceptions" [34].

It should als o be noted that "satisfaction with police is lower among residents (...) where crime is high or where fear of crime is high" [40], such as Kusow, Wilson and Martin highlight the place of residence and crime rate interference in satisfaction with police service [15].

Never forget that, according to Wells, fair and adequate treatment with citizens is the $m$ ost important instrument of their evaluation [41].

All of these factors contribute to the shaping of the GNR i mage, thus directly interfere with social representations and stereo types that the population creates about GNR officers and are responsible fo $r$ different perceptions and satisfaction of the quali ty of his work.

\subsection{Characterization of Districts under analysis}

Although space i s considered, inevitably, a physical phenomenon, it is dependent on sociological analysis, since this is where social connections are embodied and it is "the object of particular collective representations that may vary with civilizations, social c lasses, and even social groups. Moreover, space is socially ordered and, as such, influences social interactions" [6].

In this co ntext, and aft er understanding the relationship between this two sciences, it is important to separat e and mark the differences between the districts under analysis, since they are two different districts, Évora is charac terized by rural environment, sm alls towns and little population, on the other hand, $\mathrm{S}$ etúbal is characterized by urban environment and hig $\mathrm{h}$ population density.

\section{Results' Presentation, Study, Discussion}




\subsection{Interview's content analysis}

By conducting a content analy sis throughout the interviews' results of th e script appli ed to GNR officer's and specialists $\mathrm{i} n$ the Security area, we were able to identify the following common points:

Regarding which are the factors that respondents consider most important for im proving GNR militaries social representations:

- Competence and courtesy in service;

- Good posture and proper behavior;

- Type of uniform;

- The new forms of policing;

- Physical and intellectual capacity appropriate to demanding role;

- Respect for citizens;

- Dissemination of GNR's work on social networks (Facebook and Instagram);

In contrast, regarding which are the factors that respondents consider most affect the officer's image and opinion and consequently negatively condition social representations:

- The distribution of $h$ uman and logistic resources at GNR Command level;

- Place of residence, tending to poorer outcomes in densely populated centers more specific in social housing neighborhoods;

- Education/Literacy level;

- Economic capacity;

- Social class;

- Age, tending to worst in young ages;

- Culture/Values/Mores; Regarding which the adje ctives were chosen to characterize GNR officer's, currently:

- Professionals;

- Attentive;

- Competent;

- Multipurpose;

- Humble;

- Irreverent;

- Reliable;

- Well prepared for mission performance;

- Arrogant on occasion;

Regarding which the adje ctives were chosen to characterize GNR offic er's, before and at the beginning of 21 st century:

- Limited;

- Dependents;

- Low intellectual ability;

- Available;

- Aggressive;

- Gross;

- Illiterate;
- Weak at the physical level;

- Insufficient training;

\subsection{Surveys' Descriptive Statistical Analysis}

Our first question related to ascertaining whether the citizens consider or not that GNR officers transmit a credible and proximity image.

Figure 5: Officer's Proximity and Credible Image by District (Authors' Elaboration).

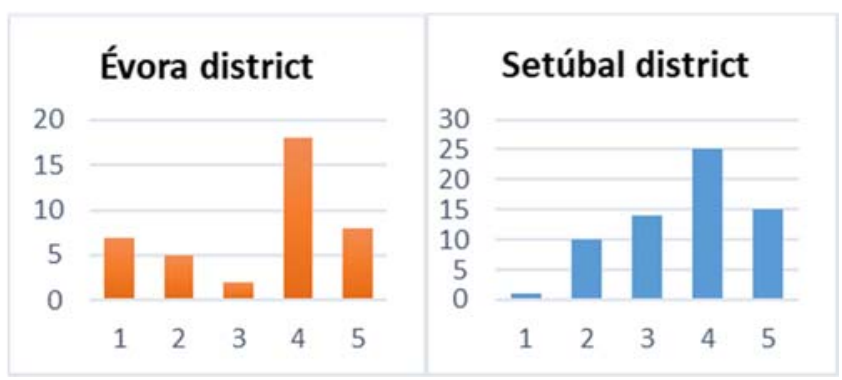

In Évora, the results are unexpectedly different from Setúbal, highlig hting the big percentage of disagreement with an of ficer's proximity image. About $17,5 \%$ disagree at all and $12,5 \%$ disagree with that, $\mathrm{t}$ his makes up $30 \%$ of respondents. However, the percentage is mostly concentrated at levels four and five with a $65 \%$ agreem ent scale distributed between them, as shown in Figure 6 .

Although $1,5 \%$ strongly disagree with credible and proximity image, $15,4 \%$ disagree with it and the remaining percentage is concentrated at level four of the scale wit h $38,5 \%$, this in Setúbal district, as shown in Figure 6.

The next question is related to ascertain whether the citizens consider or not that place of residence is important for the creation of social representations of this professional class.

Figure 6: Place of Residence Importance by District (Authors' Elaboration).

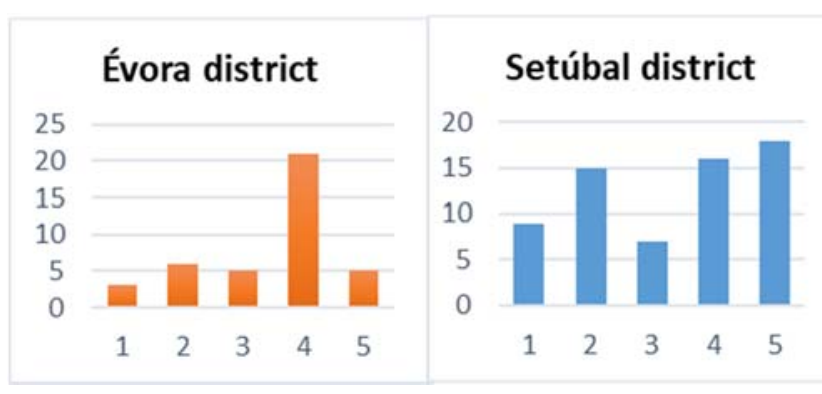

Most respondents feel that their place of residence is indeed a major factor in how they perceive GNR officers. Onl y 33 respondents, corresponds to $31 \%$, refuse that possibility. 
This disparity in results is explained, in our view, by the social and cultural asymmetries in Setúbal. In this district, there are large urban centers, num erous social neighborhoods where there is a high population density, but there are also councils imminently rural similar to those analyzed in Évora. We needed to un derstand if the current relationshi $\mathrm{p}$ between GNR officers and the population is healthy and positive.

Figure 7: Degree of Agreem ent with Current Good Relationship by District (Authors' Elaboration).

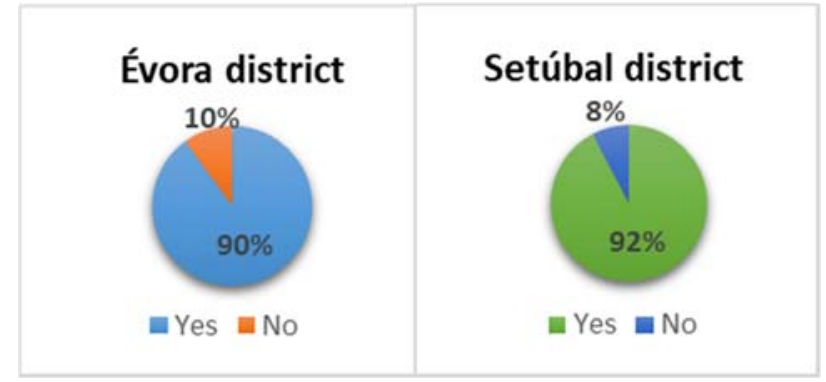

We found that in both districts the percentage of agreement is over $90 \%$, as can be seen in the previous graphs. Only an $18 \%$ rate thee current relationship as negative, it corresponds to 19 in 105 citizens that express dissatisf action with that relationship.

However, the next question asks whether the relationship between GNR officers and Portuguese citizens in the past has al ways been positive and healthy. In this question, we obtained quite different results from the previous question, as shown in the following figures.

Figure 8: Degree of Agreement with Good Relationship in the Pa st by District ( Authors' Elaboration).

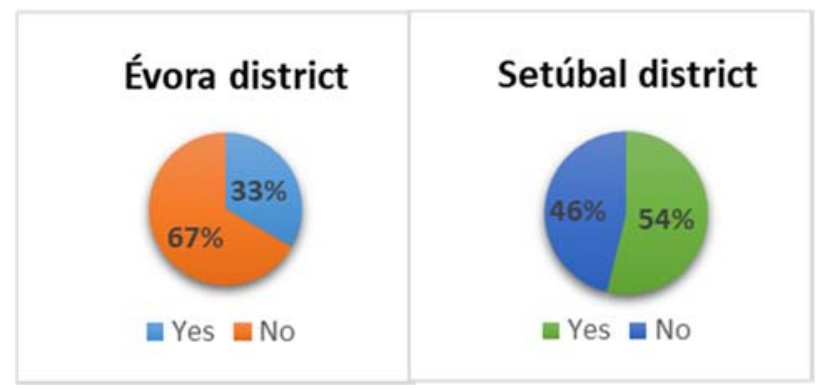

Respondents in both di stricts point out that relationship was a deficit in:

- Middle of last century, in specific in the 1960s, 1970 s, and 1980 s, this pe riod corresponds to Estado Novo, dictatorship lived in Portugal and other European countries;
- Post Estado Novo period;

In our view, a repressive and au thoritarian attitude was not intri nsic to GNR officers, it consisted only in fulfillment GNR mission during this period.

The image and opi nion of the popu lation about them was bad and derogatory because the treatment with the citizens was not the most appropriate, but it cannot be said that the o fficers were incompetent and unable to enforce the law.

In the chart below, we can see that seeks to ascertain whether respondents consider if there are greater respect and credibility in rural areas for the works carried out by GNR m ilitaries. 77\% believe so, according to figure 10, and are the result of 33 plus 48 respondents fro $\mathrm{m}$ Évora and Setúbal. Assuming, that, in rural areas, the population relates in a better way with militaries, following their guidelines and advice.

Figure 9: Degree of Agreement with greater respect and credibility in rural areas for the works carried out by GNR militaries in both district s (Authors' Elaboration).

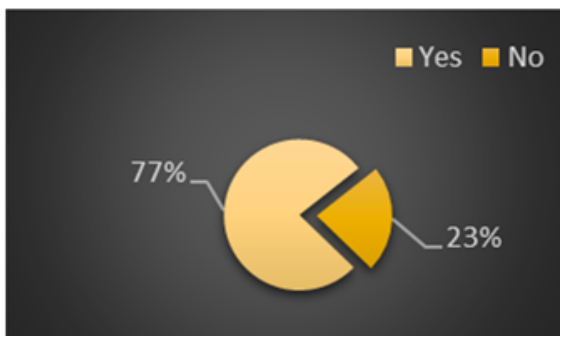

To successfully finish our survey we needed to understand the stereotype evaluation of GNR militaries. So, the last two survey questions aim to determine if the $m$ ilitaries working i n Évora and Setúbal districts fit the s tereotype created in the 1970s. Survey results indicate that repressive, aggressive, alcoholic, illiterate and authoritarian Guard figure seems to gradually fade over the y ears in both districts.

In Évora, unt il 2010, the results were worrying for the military's image because $40 \%$, according to figure 15, fit the $\mathrm{m}$ in the old stereotype created in the 70s. This view has un dergone positive changes over time, so that, in current ti mes, this percentage has fallen to $5 \%$, according to figure 16 , which means a reduction of $35 \%$ in few years.

Figure 10: Degree of Agreem ent with Stereotype Evaluation about GNR militaries in Évora (Authors' Elaboration). 


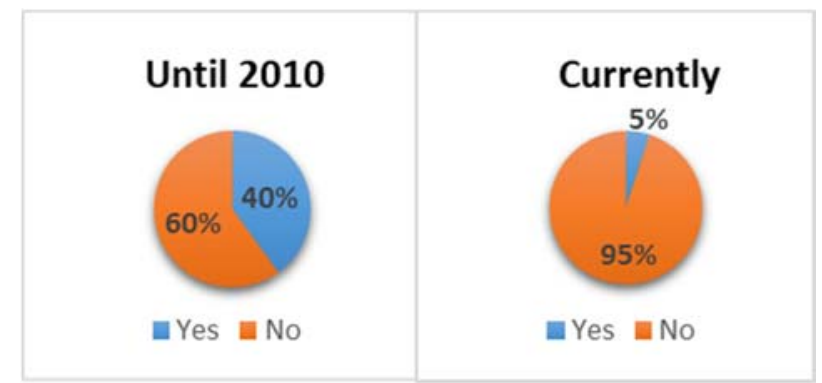

There is also an evolution, by 2010 , about $29 \%$ of respondents in Setúbal, according to figure 17, state that GNR militaries continue to be aggressive, disrespectful and authoritarian. However, this view is positively changed a $\mathrm{s}$ nowadays only $6 \%$, according to figure 18 , rank the $m$ ilitaries in such a way, which means a reduction of $23 \%$.

Figure 11: Degree of Agreem ent with Stereotype Evaluation about GNR militaries in Setuba 1 (Authors' Elaboration).

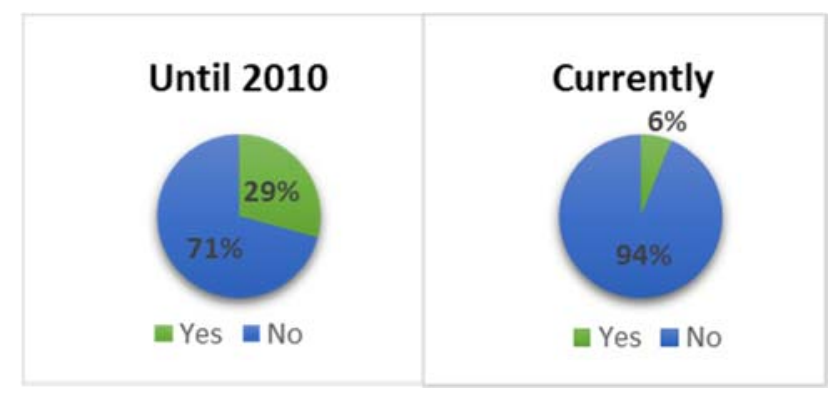

\section{Conclusions}

The study behind $\mathrm{t}$ his paper aimed to understand social representations about GNR officer's/militaries in Évora and Setúbal districts.

The research's instrumentation was carried out through selected bibliographic resources, fro $\mathrm{m}$ which several management tools we re studied, supporting and sustaining the study. From these, the central question was defined as the following: "How has been chara cterized the ev olution of GNR militaries social representation in the Territorial Commands of Évora and Setúbal, in the last eighteen years?", then we have drawn the associated sub-questions that served as the mainstay. Both the central question and the associated sub-questions were o ur focus throughout the investigation.

Nowadays, society is observing GNR e fforts to modernize and innovate processes and to instill in its military professionalism, credibility, proximity, and dedication to eliminating the ideas of corruption, abuse of authority and unfair behaviors towards citizens. Exhaustive investment information and training, besides being a constant, is justified by the fact that attitudes and behaviors influence the perception, image, and opinio $\mathrm{n}$ of citizens about militaries.

By having a representative sam ple of the population, through the surveys' interpretation we were able to understand: first, there is a disparity of results between rural a reas (Évora) and urban areas (Setúbal), where GNR military's image of proximity and confidence, as well as $\mathrm{s}$ atisfaction with police service, is most prominently fell in Setúbal district.

Secondly, in Évora a significant po pulation percentage considers that militaries do not convey the intended institutional image, that is, they regret, nowadays, the distance between citizens and officers. In previous periods, they were more present and close to citizen's problems. On the other hand, in Setúbal the image that GNR intends to transmit is what has been perceived by most citizens.

Currently, and unfortunately , complain still have a negative character. It remains, because of Estado Novo, because at that ti me those who established contact with the authorities we re immediately disreputable by the other citizens. Thus, and although not intimidating related to the military stereotype, image or opinion, there are still repercussions that haunt and hi nder GNR work, as th ere must be cooperation between society and security forces.

The stereotype of the past is practically extinct, that is, the aggressive, repressive, corrupt, illiterate and alcoholic GNR officer is no longer exists today among Portuguese population, data from the surveys confirm that. We can conclude that this derogatory stereotype has been slowly eliminated with the co mmitment and dedication of the militaries, but where time factor assu mes an enormous preponderance in this unty ing of the past.

Social representations have evolved quite positively and progressively in both districts over the last eighteen years. Increasingly, society recognizes the importance of GNR $\mathrm{m}$ ilitaries, eventually respecting and collaborating with them. However, this evaluation is a result of GNR' $s$ strong bet on bringing the officers closer to citizens and this must remain a strategic objective so that social representations, opinion, and image about GNR officers do $\mathrm{n}$ ot return to the highl y derogatory level of the previous centur y. Social representation is affect ed, fundamentally, by culture, values, place of residence of each one 
regulating and conditioning their behavior and attitudes.

Finally, there are fe w places in two districts under GNR jurisdiction, where militaries are still seen as problematic and aggressive, concluding that stereotype has evolved positively.

In last, from the study carried out, we urge the importance of military management and allocation, the logistic and financial resources $b \quad y$ GNR Territorial Command.

Satisfaction and good opinion and image with police are often associated with quick and efficient responsiveness. That is, there $m$ ust be rational distribution of resources, so as not to c ompromise military performance. If the $y$ do not have minimum conditions, at least, for the norm al performance of duty by the GN R militaries, the opinion and image of citizens regarding them will be strongly affected and, consequently, the social representations about them.

Hence, the placement of the newly formed GNR militaries/officers is also of great importance for the social representations, as they are up to date in law skills and procedures, contrasting with possible defects and lack of law skills updating of the older officers. Wher e the contra st between youth and experience can be an asset to Guarda Nacional Republicana.

\section{Challenges for Futures Researches}

In this context, it is proposed for future acade mic research challenges, to study social representations of GNR militaries, covering all Territorial Commands, including Azores and Madeira Archipelago.

\section{References:}

[1] AR. Decreto de 10 de abril de 197 6: Constituição da República Portuguesa. Diário da República, $1^{\mathrm{a}}$ série, $\mathrm{n}^{\circ}{ }^{\mathrm{o}} 86,1976$.

[2] AR. Lei n. ${ }^{\circ}$ 63/2007, de 6 de novem bro: Lei Orgânica da Guarda Nacional Repu blicana. Lisboa: Diário da República, 1. ${ }^{\mathrm{a}}$ Série, № 213, 2007.

[3] AR. Comando Geral d a Guarda Nacional Republicana 2010. Despacho n. ${ }^{\circ} 10393$, de 22 de junho. Regulamento Geral do Serviço da Guarda Nacional Repub licana. Diário da República, 2. ${ }^{\mathrm{a}}$ série, n. ${ }^{\circ} 119,2010$.

[4] AR. Decreto-Lei n. ${ }^{\circ}$ 30/ 2017, de 22 de março. Estatuto dos Militares da Guarda Nacional
Republicana. Diário da República, $1^{\mathrm{a}}$ série, $\mathrm{N}^{\mathrm{o}}$ 58, 2017.

[5] Bradford, B., Jackson, J. \& Stanko, E. Contact and confidence: revisiting the im pact of public encounters with the $\mathrm{p}$ olice. Policing and society. Vol. 19, No 1, 2009, pp. 20-46.

[6] Coster, M. \& Legros, B. Introdução à Sociologia. Lisboa: Editorial Estampa,1998.

[7] Doise, W. Attitudes et Representations Sociales. Les Representations Sociales. Paris: PUF, 1989, pp. 220-238.

[8] Easterby-Smith M.; Thorpe, R.; Jackson, P. R. \& Jastersen, L. J. Management \& Business Research. (6th Ed.). London: Sage, 2018.

[9] Flanagan, R. The Review of Policing: Final Report. London: Home Office, 2008.

[10] Fortin, M. F. O Processo de Investigação: Da concepção à realização, 5a Edição. Loures, Lusociência, 2009.

[11] Giddens, A. Sociologia. Lisboa: Fundação Calouste Gulbenkian, 2010.

[12] Guarda Nacional Republicana [GNR] Estratégia da Guarda 2020 - Uma estratégia de futuro. Lisboa: Divisão de Plane amento Estratégico e Relações Internacionais, 2014.

[13] Gresle, C. H. F. História da Sociologia. Lisboa: D. Quixote, 1995.

[14] Jodelet, D. Les représentations Sociales. Paris: Presses Universitaires de France, 1989.

[15] Kusow, A.; Wilson, L. C. \& Martin, D. Determinants of citizen satisfaction with the police: the effects of residential location. Policing: An International Journal of Police Strategies \& Management, Vol. 20, No 4, 1987, pp. 655-664.

[16] Lindon, D., Lendrevie, J., Lévy, J. \& Díonísio, P. Mercator XXI. Lisboa: Dom Quixote, 2000.

[17] Marconi, M. A. \& Lakato s, E. M. Técnicas de Pesquisa. São Paulo: Editora Atla, 1982.

[18] Marcos, A. and Loureiro, G. Excelência no atendimento e boas práticas no serviço público, (1 ${ }^{\mathrm{a}}$ ed.). Prefeitura de Vitória, 2017.

[19] Moscovici, S. Social representations. Explorations in social psychology. New York: New York University Press, 2001.

[20] Negreiros, M. As Repr esentações Sociais da Profissão de Serviço Social. Intervenção Social, 2014, pp. 81-104.

[21] Neto, F. Psicologia Social, Vol. 1, Lisboa: Universidade Aberta, 1988.

[22] O'Donnell, W. \& Archibald, D. The Collected Works of William Butler Yeats. New York: Scribner, 1999.

[23] Oliveira, J. F. As políticas de Segurança e os Modelos de Policiamento - A emergência do 
policiamento de proximidade. Coimbra: Almedina, 2006.

[24] Online Etymology Dictionary, available at www.etymonline.com, accessed on 15th and 22nd November 2019.

[25] Online Longman Dictionary of Conte mporary English, available at www.idoceonline.com , accessed on 15th November 2019.

[26] Pacheco, J. Representações Sociais do suicídio em futuros Comandantes de Polícia. Mestrado em Ciências Policiais, Instituto Superior de Ciências Policiais e Segurança Interna, Lisboa, 2016.

[27] Pereira, P. A Importância da GNR para o Cidadão: Estudo de caso dos concelhos de Mafra e Sintra. Trabalho de inve stigação aplicada, Mestrado em Ciências Militares, Academia Militar, Lisboa, 2015.

[28] Quivy, R. \& Cam penhoudt, L. V. Manual de Investigação em Ciências Sociais, $5^{\text {a }}$ Edição. Lisboa, Gradiva, 2008.

[29] Reiner, R. The Politics of the Police. Oxford: Oxford, University Press, 2010.

[30] Rosado, D. P. Elementos Essenciais de Sociologia Geral. Lisboa, Gradiva, 2017.

[31] Ruão, T. 20 05. O papel da identidade e da imagem na gestão das universidades. Livro de Actas $-4^{\circ}$ SOPCOM, Br aga: Universidade do Minho.

[32] Sampaio, D., Oliveira, A. Vinagre, M. Pereira, M. Santos, N. \& Orda z, O. Repres entações sociais do suicídio em adolescente $\mathrm{s}-\mathrm{As}$ explicações dos jovens. Análise Psicológica, Vol. 18, No 2, 2010, pp. 139-155.

[33] Sarmento, M. Metodologia Científica para a elaboração, escrita e apresentação de teses. Lisboa: Universidade Lusíada de Lisboa, 2013.

[34] Schafer, J., Huebner, B. \& By num, T. Citizen perceptions of the police $\mathrm{s}$ ervices: race, neighborhood context and community policing. Police Quarterly, Vol 6, № 4, 200 3, pp. 440468.

[35] Skogan, W. Citizen satisfaction with police encounters. Police Quarterly, Vol 8, $\mathrm{N}^{\mathrm{o}} 3$, 2005, pp. 298-321.

[36] Thomassen, G, Strype, J. \& Egge, M. Trust no matter what? Citizens Perception of the Police 1 year after the terror attacks in Norway. Policing. Vol 8, № 1, 2013, pp. 79-87.

[37] Tyler, T. Enhancing polic y legitimacy. Annals of the American Academy of Political \& Social Science, Vol. 593, 2004, pp. 84-99.

[38] Tyler, T \& Huo, Y. Trust in the Law. New York: Russell Sage Foundation, 2002.
[39] Tyler, T \& Wakslak, C. Profiling, and police legitimacy: Procedural justice, attributions of motive and acceptance of police authority. Criminology, Vol. 42, No 2, 2006, pp. 253-81.

[40] Weitzer, R. \& Tuch, S. Determ inants of public satisfaction with the Police. Police Quarterly, Vol. 8, No 3, 2005, pp. 279-297.

[41] Wells, W. Type of contact and evalua tions of police officers: the effects of procedural justice across three types of police-citizen contacts. Journal of Criminal Justice, Vol. 35, 2007, pp. 612-21.

[42] Vilela, G. 2009. Metodologia da Pesquisa científica. Accessed on 15th and 22nd November 2019 in https://issuu.com/ 